\title{
STABLE ISOTOPES OF HYDROGEN AND OXYGEN IN SURFACE WATER AND GROUND WATER AT SELECTED SITES ON OR NEAR THE IDAHO NATIONAL ENGINEERING LABORATORY, IDAHO
}

By Douglas S. Ott, L. DeWayne Cecil, and LeRoy L. Knobel

\section{U.S. GEOLOGICAL SURVEY}

Open File Report 94-55

Prepared in cooperation with the U.S. DEPARTMENT OF ENERGY

Idaho Falls, Idaho

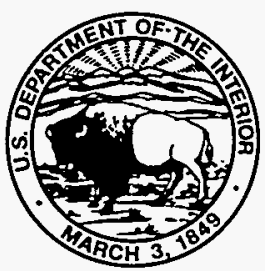

1994

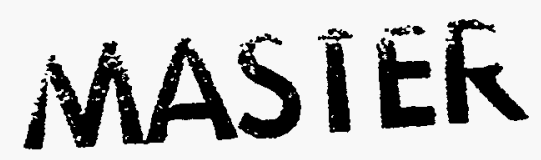




\section{U.S. DEPARTMENT OF THE INTERIOR BRUCE BABBITT, Secretary \\ U.S. GEOLOGICAL SURVEY \\ Robert M. Hirsch, Acting Director}

For additional information write to:

Project Chief

U.S. Geological Survey

INEL, MS 4148

P.O. Box 2230

Idaho Falls, ID 83403
Copies of this report can be purchased from:

U.S. Geological Survey

Earth Science Information Center

Open-File Reports Section

Box 25286, Mail Stop 517

Denver Federal Center

Denver, CO 80225 


\section{DISCLAIMER}

This report was prepared as an account of work sponsored by an agency of the United States Government. Neither the United States Government nor any agency thereof, nor any of their employees, make any warranty, express or implied, or assumes any legal liability or responsibility for the accuracy, completeness, or usefulness of any information, apparatus, product, or process disclosed, or represents that its use would not infringe privately owned rights. Reference herein to any specific commercial product, process, or service by trade name, trademark, manufacturer, or otherwise does not necessarily constitute or imply its endorsement, recommendation, or favoring by the United States Government or any agency thereof. The views and opinions of authors expressed herein do not necessarily state or reflect those of the United States Government or any agency thereof. 


\section{DISCLAIMER}

Portions of this document may be illegible in electronic image products. Images are produced from the best available original document. 


\section{CONTENTS}

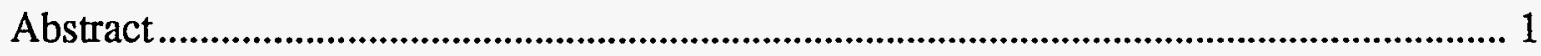

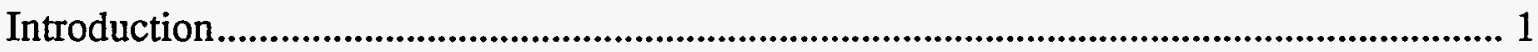

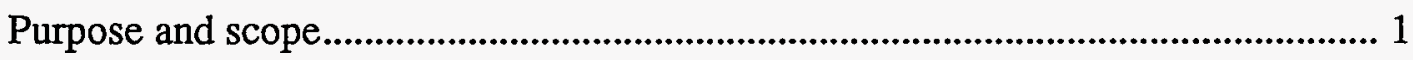

Hydrologic conditions............................................................................................ 3

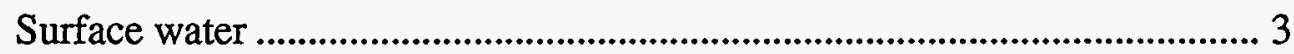

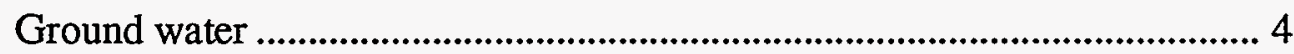

Previous investigations ............................................................................................ 4

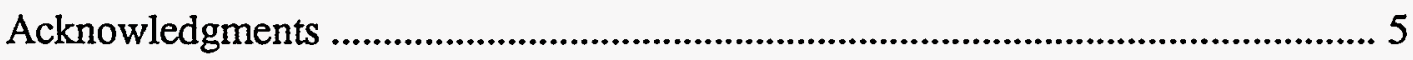

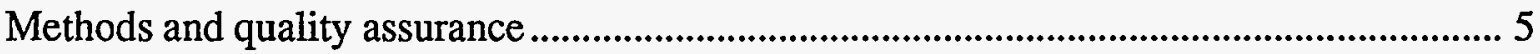

Sample containers ............................................................................................ 5

Sample locations and sample collection .......................................................... 5

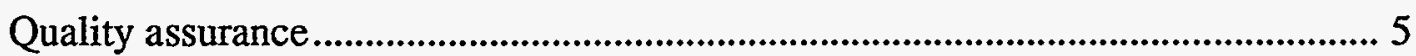

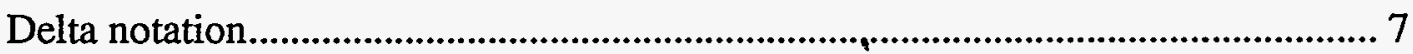

Stable isotopes of hydrogen and oxygen ..................................................................... 7

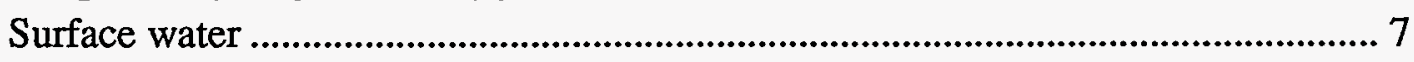

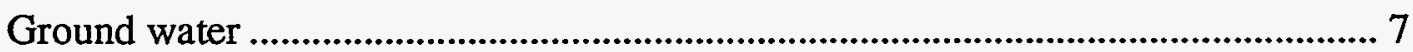

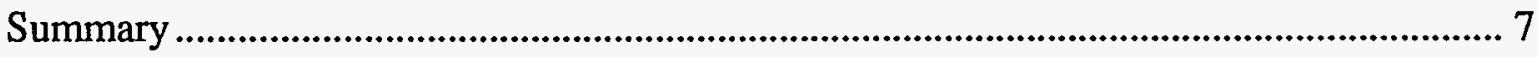

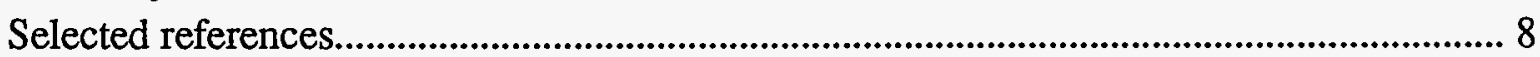

\section{FIGURES}

Figures 1-2. Maps showing:

1. Locations of the Idaho National Engineering Laboratory, surface-water sampling sites, and selected facilities............................................................... 2

2. Locations of ground-water sampling sites ..................................................... 6

TABLES

Table 1. Stable isotopes of hydrogen and oxygen for Big Lost River below Mackay Reservoir near Mackay, Idaho (13127000)............................................................ 9

2. Stable isotopes of hydrogen and oxygen for Little Lost River near Howe,

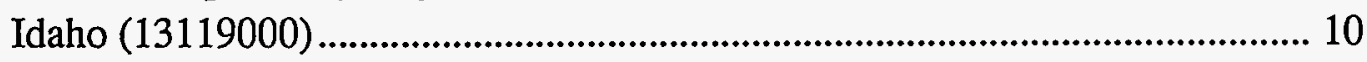

3. Stable isotopes of hydrogen and oxygen for Birch Creek at Blue Dome Inn near Reno, Idaho (13117020)............................................................................ 11

4. Stable isotopes of hydrogen and oxygen for Mud Lake near Terreton, Idaho (13115000)

5. Stable isotopes of hydrogen and oxygen for selected wells and a spring on or near the Idaho National Engineering Laboratory, Idaho 


\section{CONVERSION FACTORS, VERTICAL DATUM, AND ABBREVIATED UNITS}

Multiply

inch (in.)

foot $(\mathrm{ft})$

foot per mile $(\mathrm{ft} / \mathrm{mi})$

mile (mi)

square mile $\left(\mathrm{mi}^{2}\right)$

acre-foot (acre-ft)

cubic foot per second $\left(\mathrm{ft}^{3} / \mathrm{s}\right)$
By

25.4

0.3048

0.1894

1.609

0.001233

0.02832
To Obtain millimeter meter meter per kilometer kilometer square kilometer cubic hectometer cubic meter per second

Sea Level: In this report, "sea level" refers to the National Geodetic Vertical Datum of 1929-a geodetic datum derived from a general adjustment of the first-order level nets of the United States an Canada, formerly called Sea Level Datum of 1929.

Abbreviated units used in report: milliliter (mL). 


\title{
STABLE ISOTOPES OF HYDROGEN AND OXYGEN IN SURFACE WATER AND GROUND WATER AT SELECTED SITES ON OR NEAR THE IDAHO NATIONAL ENGINEERING LABORATORY, IDAHO
}

\author{
by Douglas S. Ott, L. DeWayne Cecil, and LeRoy L. Knobel
}

\section{Abstract}

Relative stable isotopic ratios for hydrogen and oxygen compared to standard mean ocean water are presented for water from 4 surfacewater sites and 38 ground-water sites on or near the Idaho National Engineering Laboratory (INEL). The surface-water samples were collected monthly from March 1991 through April 1992 and after a storm event on June 18, 1992. The ground-water samples either were collected during 1991 or 1992. These data were collected as part of the U.S. Geological Survey's continuing hydrogeological investigations at the INEL.

The relative isotopic ratios of hydrogen and oxygen are reported as delta ${ }^{2} \mathrm{H}\left(\delta^{2} \mathrm{H}\right)$ and as delta ${ }^{18} \mathrm{O}\left(\delta^{18} \mathrm{O}\right)$, respectively. The values of $\delta^{2} \mathrm{H}$ and $\delta^{18} \mathrm{O}$ in water from the four surfacewater sites ranged from -143.0 to -122 and from -18.75 to -15.55 , respectively. The values of $\delta^{2} \mathrm{H}$ and $\delta^{18} \mathrm{O}$ in water from the 38 ground-water sites ranged from -141.0 to -120.0 and from -18.55 to -14.95 , respectively.

\section{INTRODUCTION}

The Idaho National Engineering Laboratory (INEL), encompassing about $890 \mathrm{mi}^{2}$ of the eastern Snake River Plain in southeastem Idaho (fig. 1), is operated by the U.S. Department of Energy. INEL facilities are used in the development of peacetime atomic-energy applications, nuclear safety research, defense programs, and advanced energy concepts. Wastewater containing radionuclide and chemical constituents generated at these facilities has been discharged to onsite infiltration ponds and disposal wells since 1952. Wastewater disposal has resulted in detectable concentrations of several constituents in water from the Snake.River Plain aquifer underlying the INEL.

The U.S. Department of Energy requires information about the mobility of dilute radionuclideand chemical-waste constituents in water in the Snake River Plain aquifer. Waste-constituent mobility is, in part, determined by (1) the rate and direction of ground-water flow; (2) the locations, quantities, and methods of waste disposal; (3) waste-constituent chemistry; and (4) the geochemical processes taking place in the aquifer (Orr and Cecil, 1991, p. 2). This study was conducted by the U.S. Geological Survey (USGS) in cooperation with the U.S. Department of Energy's Idaho Operations Office.

\section{Purpose and Scope}

In 1949, the U.S. Atomic Energy Commission, later to become the U.S. Department of Energy, requested that the USGS describe the water 


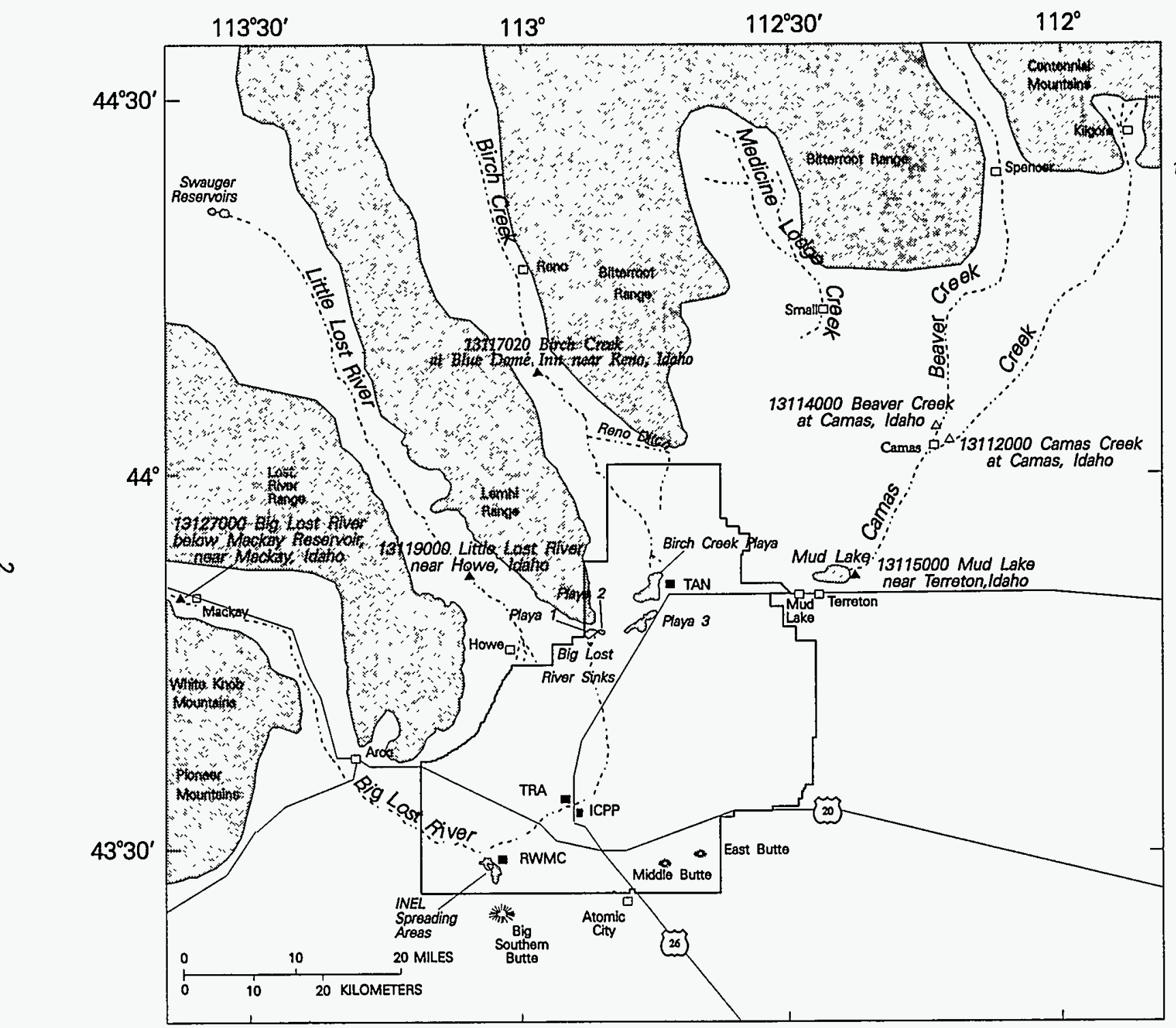

\section{EXPLANATION}

BOUNDARY OF IDAHO NATIONAL ENGINEERING LABORATORY

13114000 Beaver

creak at $\triangle$ STREAMFLOW-GAGING STATION Camas, Idaho AND IDENTIFIER

13115000 Mud

STREAMFLOW-GAGING STATION Terroton, Idaho WHERE SAMPLE WAS COLLECTED AND IDENTIFIER

- SELECTED FACILITIES AT THE IDAHO NATIONAL ENGINEERING LABORATORY ICPP IDAHO CHEMICAL PROCESSING

RWMC RADIOACTIVE WASTE

TRA TEST REACTORS AREA

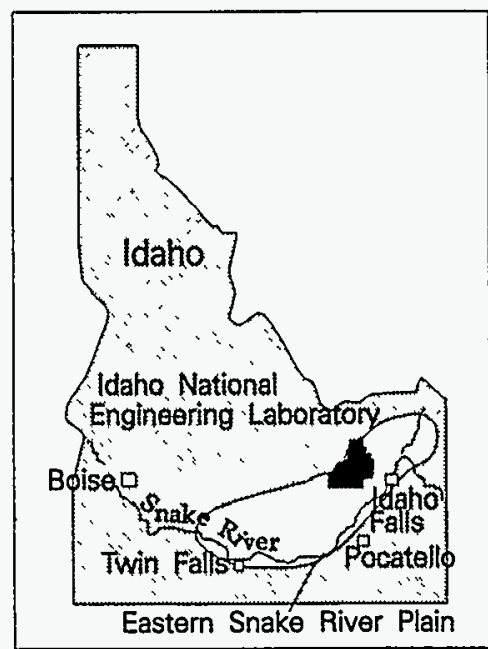

Figure 1.-Locations of the Idaho National Engineering Laboratory, surface-water sampling sites, and selected facilities. 
resources of the area now known as the INEL. The purpose of that study was to characterize these resources prior to the development of nuclear reactor testing facilities. Since 1949, the USGS has maintained a monitoring network at the INEL to determine hydrologic trends and to delineate the movement of facility-related radionuclide and chemical wastes in the Snake River Plain aquifer.

This report presents a compilation of hydrogen $(\mathrm{H})$ and oxygen $(\mathrm{O})$ isotope data collected during 1991-92 from the Snake River Plain aquifer and selected surface sites on tributary drainages to the Snake River Basin. The data were collected as part of the continuing hydrogeologic investigations at the INEL.

\section{Hydrologic Conditions}

The Snake River Plain aquifer is one of the most productive aquifers in the United States (U.S. Geological Survey, 1985, p. 193). The aquifer underlies the eastern Snake River Plain and consists of a thick sequence of basalts and sedimentary interbeds filling a large, arcuate, structural basin in southeastern Idaho (fig. 1).

\section{Surface Water}

Stable isotope samples for $\mathrm{H}$ and $\mathrm{O}$ were collected at several streamflow-gaging stations to characterize the isotopic composition of surface water in the upper reaches of the Big Lost and Little Lost Rivers, Birch Creek, and Camas Creek-a tributary basin to Mud Lake.

The Big Lost River drains more than $1,400 \mathrm{mi}^{2}$ of mountainous area that includes parts of the Lost River Range and Pioneer Mountains west of the INEL (fig. 1). Flow in the Big Lost River infiltrates to the Snake River Plain aquifer along its channel and at sinks and playas at the river's terminus. Since 1958, excess runoff has been diverted to spreading areas in the southwestern part of the INEL (fig. 1) where much of the water rapidly infiltrates to the aquifer (Orr and Cecil, 1991, p. 23). Water samples were collected at the
USGS gaging station on the Big Lost River below Mackay Reservoir. The drainage area for this station is $813 \mathrm{mi}^{2}$ and the average discharge for 75 years of record is $309 \mathrm{ft}^{3} / \mathrm{s}$ (Harenberg and others, 1992, p. 179).

The Little Lost River drains more than $700 \mathrm{mi}^{2}$ of mountainous area that includes parts of the Lost River Range and Lemhi Range northwest of the INEL (fig. 1). Flow in the Little Lost River infiltrates to the Snake River Plain aquifer along the lower reach of its channel and at sinks and playas at the river's terminus. Since 1984, water has been diverted for flood control 1 mi upstream from the gaging station near Howe. The average discharge for 44 years of record is $77.1 \mathrm{ft}^{3} / \mathrm{s}$ (Harenberg and others, 1989, p. 229).

Birch Creek drains the mountainous area north of the INEL that includes parts of the Lemhi Range and Bitterroot Range. Natural flow in Birch Creek infiltrates to the Snake River Plain aquifer along its channel and at sinks and playas at the creek's terminus (Stearns and Bryan, 1925, p. 106). From about 1900 to April 1987, flow from Birch Creek was diverted through Reno Ditch for irrigation during the growing season. Since April 1987, flow has been diverted for power generation and returned either to Reno Ditch for irrigation or to a canal that routes it to the northem part of the INEL (Ted Sorenson, Sorenson \& Associates Consulting Engineers, oral commun., 1992). Isotope samples were collected from Birch Creek about $5 \mathrm{mi}$ upstream from the diversion at the USGS's gaging station at Blue Dome Inn near Reno, Idaho. The drainage area for the station is $380 \mathrm{mi}^{2}$ and the average discharge for 6 years of record is $77.5 \mathrm{ft}^{3} / \mathrm{s}$ (Harenberg and others, 1992, p. 174).

Camas Creek and Beaver Creek drain the mountainous area northeast of the INEL that includes parts of the Bitterroot Range and the Centennial Mountains. The two creeks join near Camas and flow into Mud Lake. Isotope samples were collected from flowing water in Camas Creek at the USGS gaging station, Mud Lake near Terreton, Idaho. The streamflow gage-Beaver 
Creek at Camas, Idaho-measures discharge from an area of $510 \mathrm{mi}^{2}$ and is located $1.4 \mathrm{mi}$ upstream from the mouth. The average discharge for 52 years of record is $5.8 \mathrm{ft}^{3} / \mathrm{s}$. The streamflow gage-Camas Creek at Camas, Idaho-measures discharge from an area of $400 \mathrm{mi}^{2}$ and is located $1.1 \mathrm{mi}$ upstream from the confluence with Beaver Creek. The average discharge for 59 years of record is $35 \mathrm{ft}^{3} / \mathrm{s}$. The combined drainage area for these two streams makes up the bulk of the $1,130 \mathrm{mi}^{2}$ drainage area for the gage where the samples were collected (Harenberg and others, 1992, p. 169, 171-172).

\section{Ground Water}

Stable isotope samples for $\mathrm{H}$ and $\mathrm{O}$ were collected from selected wells and a spring on or near the INEL to characterize the isotopic composition of water from the Snake River Plain aquifer.

Recharge to the Snake River Plain aquifer is principally from infiltration of applied irrigation water, infiltration of streamflow, and alluvial ground-water inflow from adjoining mountain drainage basins. Some recharge may be from direct infiltration of precipitation, although the small amount of annual precipitation on the plain ( 8 in. at the INEL), evapotranspiration, and the great depth to water (in places exceeding $900 \mathrm{ft}$ ) probably minimize this source of recharge (Orr and Cecil, 1991, p. 22-23).

Water in the Snake River Plain aquifer moves principally through fractures and interflow zones in the basalt. A significant proportion of ground water moves through the upper $800 \mathrm{ft}$ of saturated rocks (Mann, 1986, p. 21). Hydraulic conductivity of basalt in the upper $800 \mathrm{ft}$ of the aquifer generally is 1 to $100 \mathrm{ft} /$ day. Hydraulic conductivity of underlying rocks is several orders of magnitude smaller. The effective base of the Snake River Plain aquifer at the INEL probably ranges from about 850 to $1,220 \mathrm{ft}$ below land surface (Orr and Cecil, 1991, p. 25).
Depth to water in wells completed in the Snake River Plain aquifer ranges from about $200 \mathrm{ft}$ in the northem part of the INEL to more than $900 \mathrm{ft}$ in the southeastern part. In July 1988, the altitude of the water table was about $4,590 \mathrm{ft}$ above sea level near Test Area North (TAN) and about 4,420 ft near the Radioactive Waste Management Complex (RWMC). Water flowed southward and southwestward beneath the INEL at an average hydraulic gradient of about $4 \mathrm{ft} / \mathrm{mi}$. Locally, however, the hydraulic gradient ranged from about 1 to $15 \mathrm{ft} / \mathrm{mi}$. From July 1985 to July 1988, waterlevel changes in INEL wells ranged from a $26.8-\mathrm{ft}$ decline near the RWMC to a 4.3-ft rise north of TAN. Water levels generally declined in the southem two-thirds of the INEL during that time and rose in the northem one-third (Orr and Cecil, 1991, p. 25-27).

Ground water moves southwestward from the INEL and eventually is discharged to springs along the Snake River downstream from Twin Falls, about $100 \mathrm{mi}$ southwest of the INEL. About 4.3 million acre-ft of ground water were discharged to these springs in 1988 (Mann, 1989, p. 2).

\section{Previous Investigations}

The USGS has conducted geologic, hydrologic, and water-quality investigations at the INEL since it was selected as a reactor testing area in 1949. An investigation of the hydrogeology and geochemistry of the unsaturated zone at the RWMC was conducted by Rightmire and Lewis (1987). They used stable isotopes of $\mathrm{H}$ and/or $\mathrm{O}$ to differentiate sources of recharge to the Snake River Plain aquifer and perched-water bodies, to tentatively identify historical changes in climatic conditions, and to determine whether clay minerals were detrital or authigenic in origin.

In study of the solute geochemistry of the Snake River Plain regional aquifer system, Wood and Low (1988) used stable isotopes of $\mathrm{H}$ and $\mathrm{O}$ to determine the origin of recharge water to the Snake 
River Plain aquifer and the origin of water in the geothermal system in the Snake River Basin. In addition, stable isotope data of $\mathrm{H}$ and $\mathrm{O}$ were reported by Spinazola and others (1992) for water samples from five wells near Mud Lake.

\section{Acknowledgments}

The authors gratefully acknowledge the well owners for granting permission to collect water samples. Thanks are extended to Roy $\mathrm{C}$. Bartholomay and Beverly Stephens of the USGS for technically reviewing the manuscript.

\section{METHODS AND QUALITY ASSURANCE}

The methodology used in sampling for hydrogen and oxygen isotopes generally followed the guidelines established by the USGS (Claassen, 1982; Pritt and Jones, 1989; R.J. Pickering, USGS, written commun., 1981). Field methods, quality assurance practices, and delta notation are outlined in the following sections.

\section{Sample Containers}

Sample containers were either $125-\mathrm{mL}$ amber glass or 125-mL polyethylene bottles with polyseal caps. Samples analyzed by the USGS's National Water Quality Laboratory (NWQL) were placed in containers and processed in accordance with laboratory requirements specified by Pritt and Jones (1989). Containers were supplied by the NWQL and had undergone a rigorous quality control procedure (Pritt, 1989, p. 75) to eliminate sample contamination.

\section{Sample Locations and Sample Collection}

Samples were collected from 4 surface-water sites (tables 1-4), 1 irrigation well (table 5), 3 domestic wells (table 5), 4 production wells (table 5), 29 water-quality monitoring wells (table 5), and 1 commercial spring (table 5). Sample site locations are shown in figures 1 and 2. Surfacewater sites were sampled by collecting a grab sample from an area of moving water at a specified point. The irrigation well was equipped with a line-shaft turbine pump and was sampled from the center of the discharge line at the wellhead.

Domestic wells were equipped with submersible pumps and were sampled from the spigot nearest the wellhead. Production wells were equipped with line-shaft turbine pumps and were sampled at the spigot in their discharge lines. The waterquality monitoring wells were equipped with dedicated submersible pumps and were sampled from a portable sampling apparatus that was attached at the wellhead. The spring sample was taken from a spigot in the discharge line that collects water from the spring. All portable equipment was decontaminated before and after sample collection.

Prior to sampling, all wells were pumped a minimum of three well-bore volumes until water chemistry stabilized as evidenced by constant temperature, $\mathrm{pH}$, and specific conductance measurements. After collection, sample containers were sealed with black tape and laboratory film, labeled, and stored under secured conditions. The containers then were packed in ice chests, sealed, and shipped to the NWQL.

Conditions at the sampling site during sample collection were recorded in a field logbook and a chain-of-custody record was used to track samples from time of collection until delivery to the NWQL. These records are available for inspection at the USGS Project Office at the INEL.

\section{Quality Assurance}

A detailed description of internal quality control and of overall quality assurance practices used by the USGS's NWQL were provided in reports by Friedman and Erdman (1982) and Jones (1987). The water samples were collected in accordance with the USGS, INEL Project Office, Quality Assurance Plan and Field Methods for 


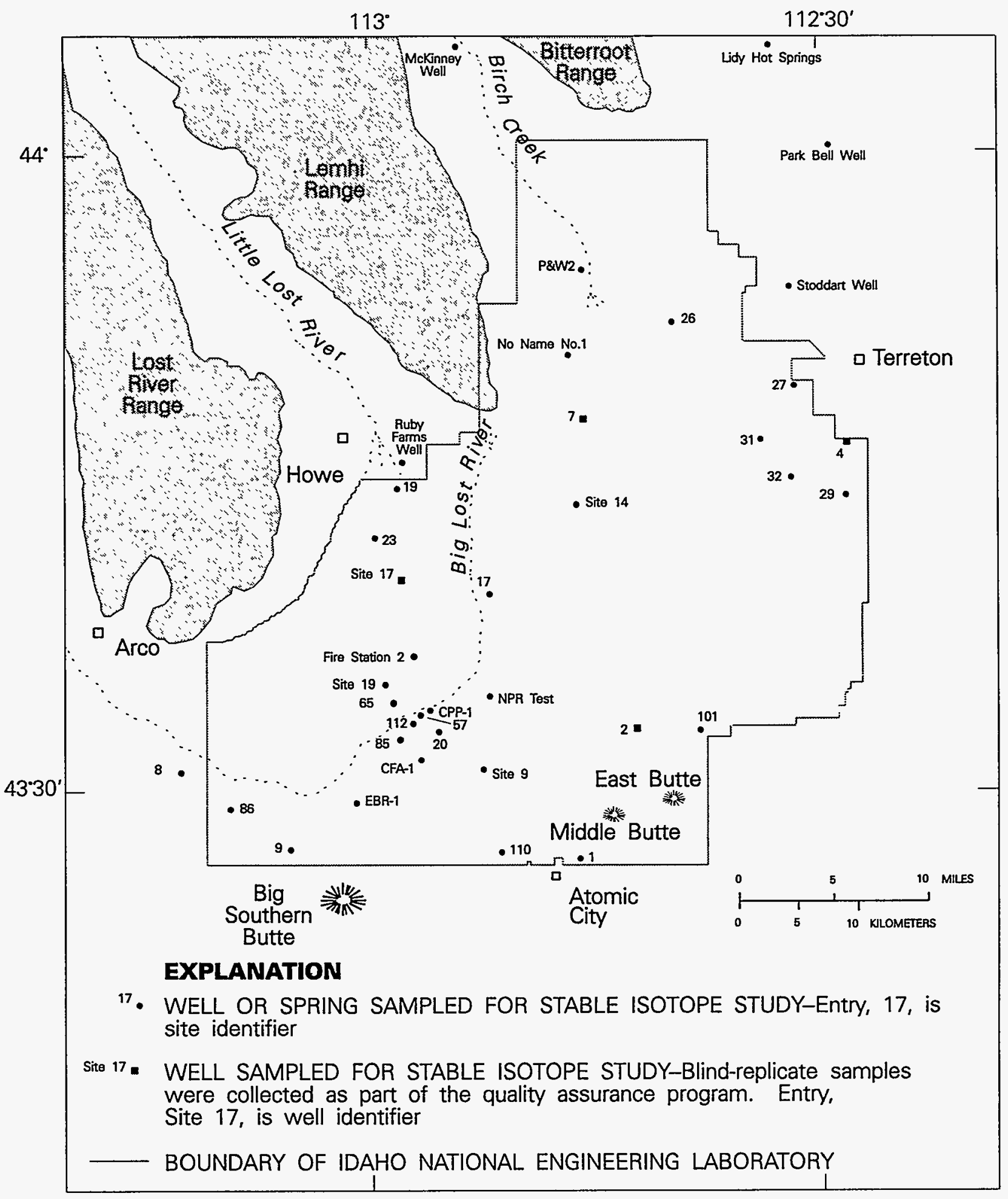

Figure 2.-Locations of ground-water sampling sites. 
Quality of Water Activities. This plan is available for inspection at the INEL Project Office.

Additional quality assurance instituted for this study included four blind-replicate ground-water samples. Stable $\mathrm{H}$ and $\mathrm{O}$ measurements in the blind-replicate samples (QAC-1, QAC-2, QAC-3, and QAC-4) were the same as in the primary samples (USGS 7, USGS 2, USGS 4, and Site 17), given the analytical uncertainties.

\section{Delta Notation}

The absolute measurement of isotopic ratios is a difficult analytical task and, as a result, relative isotopic ratios are measured as a matter of convention (Toran, 1982). For example,

${ }^{18} \mathrm{O} /{ }^{16} \mathrm{O}$ of a sample is compared to ${ }^{18} \mathrm{O} /{ }^{16} \mathrm{O}$ of a standard:

$\delta^{18} \mathrm{O}=\left(\mathrm{R}_{\text {sample }} / \mathrm{R}_{\text {standard }}-1\right) \times 1,000$, where

$\mathrm{R}_{\text {sample }}={ }^{18} \mathrm{O} /{ }^{16} \mathrm{O}$ in the sample,

$\mathrm{R}_{\text {standard }}={ }^{18} \mathrm{O} /{ }^{16} \mathrm{O}$ in the standard, and

$\delta^{18} \mathrm{O}=$ relative difference in concentration, in units of parts per thousand (permil).

Delta ${ }^{18} \mathrm{O}\left(\delta^{18} \mathrm{O}\right)$ is referred to as delta notation and is the value reported by isotopic laboratories for stable isotope analysis. $\delta^{2} \mathrm{H}$ can be derived by analogy to $\delta^{18} \mathrm{O}$ where the ratio ${ }^{2} \mathrm{H} / \mathrm{H}$ replaces ${ }^{18} \mathrm{O} /{ }^{16} \mathrm{O}$ in $\mathrm{R}_{\text {sample }}$ and $\mathrm{R}_{\text {standard. The standard }}$ used for determining $\delta^{18} \mathrm{O}$ and $\delta^{2} \mathrm{H}$ in water is standard mean ocean water (SMOW) as defined by Craig (1961). The respective precisions of measurement for $\delta^{18} \mathrm{O}$ and $\delta^{2} \mathrm{H}$ at the NWQL are 0.15 permil and 1.5 permil at the 95 -percent confidence level(Ann Mullin, USGS, oral commun., 1991; Carol Kendall, USGS, oral commun., 1994).

\section{STABLE ISOTOPES OF HYDROGEN AND OXYGEN}

Water samples were collected and analyzed for concentrations of stable isotopes of $\mathrm{H}$ and $\mathrm{O}$ at 4 surface-water sites (fig. 1) and 38 ground-water sites (fig. 2). The surface-water sites were sampled monthly from March 1991 through April 1992 and after a storm event on June 18, 1992 (tables 1-4). The ground-water sites were sampled one time each during 1991 or 1992.

\section{Surface Water}

Relative isotopic ratios reported as $\delta^{2} \mathrm{H}$ and $\delta^{18} \mathrm{O}$ for water from the Big Lost River below Mackay Reservoir near Mackay, Idaho ranged from -138.0 to -129.0 permil and from -18.00 to -17.05 permil, respectively (table 1 ). The values of $\delta^{2} \mathrm{H}$ and $\delta^{18} \mathrm{O}$ for water from the Little Lost River near Howe, Idaho ranged from -139.0 to -136.0 permil and from -18.25 to -17.80 permil, respectively (table 2 ). The values of $\delta^{2} \mathrm{H}$ and $\delta^{18} \mathrm{O}$ for water from Birch Creek at Blue Dome Inn near Reno, Idaho ranged from -143.0 to -140.0 permil and from -18.75 to -18.55 permil, respectively (table 3). The values of $\delta^{2} \mathrm{H}$ and $\delta^{18} \mathrm{O}$ for water from Mud Lake near Terreton, Idaho ranged from -135.0 to -122 permil and from -17.85 to -15.55 permil, respectively (table 4 ).

\section{Ground Water}

Relative isotopic ratios reported as $\delta^{2} \mathrm{H}$ and $\delta^{18} \mathrm{O}$ for water from the 38 ground-water sites ranged from -141.0 to -120.0 permil and from -18.55 to -14.95 permil, respectively (table 5).

\section{SUMMARY}

This report presents relative stable isotopic ratios of hydrogen and oxygen (reported as $\delta^{2} \mathrm{H}$ and $\delta^{18} \mathrm{O}$, respectively) in water from 4 surfacewater and 38 ground-water sites on or near the INEL. The four surface-water sites were sampled monthly from March 1991 through April 1992 and once after a storm event on June 18, 1992. The 38 ground-water sites were sampled one time each in 1991 or 1992. These data were collected as part of 
the USGS's continuing hydrogeologic investigations at the INEL.

The relative ratios reported as $\delta^{2} \mathrm{H}$ and $\delta^{18} \mathrm{O}$ in water from the four surface-water sites ranged from -143.0 to -122 permil and from -18.75 to -15.55 permil, respectively. The values of $\delta^{2} \mathrm{H}$ and $\delta^{18} \mathrm{O}$ for water from the 38 ground-water sites ranged from -141.0 to -120.0 permil and from -18.55 to -14.95 permil, respectively.

\section{SELECTED REFERENCES}

Claassen, H.C., 1982, Guidelines and techniques for obtaining water samples that accurately represent the water chemistry of an aquifer: U.S. Geological Survey Open-File Report 82-1024, 49 p.

Craig, Harmon, 1961, Isotopic variations in meteoric waters: Science, v. 133, p. 1,702-1,703.

Friedman, L.C., and Erdmann, D.E., 1982, Quality assurance practices for the chemical and biological analyses of water and fluvial sediments: U.S. Geological Survey Techniques of WaterResources Investigations, book 5, chap. A6, 181 p.

Harenberg, W.A., Jones, M.L., O'Dell, Ivalou, Brennan, T.S., and Lehmann, A.K., 1992, Water resources data, Idaho, water year 1991-Volume 1. Great Basin and Snake River Basin above King Hill: U.S. Geological Survey Water-Data Report ID-91-1, 337 p.

Harenberg, W.A., Jones, M.L, O'Dell, Ivalou, and Cordes, S.C., 1989, Water resources data, Idaho, water year 1988: U.S. Geological Survey WaterData Report ID-88-1, 669 p.

Jones, B.E., 1987, Quality control manual of the U.S. Geological Survey's National Water Quality Laboratory: U.S. Geological Survey Open-File Report 87-457, 17 p.

Mann, L.J., 1986, Hydraulic properties of rock units and chemical quality of water for INEL-1-a 10,365-foot deep test hole drilled at the Idaho National Engineering Laboratory, Idaho: U.S. Geological Survey Water-Resources Investigations Report 86-4020 (DOE/ID-22070), $23 \mathrm{p}$.

---- 1989, Tritium concentrations in flow from selected springs that discharge to the Snake River, Twin Falls-Hagerman area, Idaho: U.S. Geological Survey Water-Resources Investigations Report 89-4156 (DOE/ID-22084), 20 p.
Orr, B.R., and Cecil, L.D., 1991, Hydrologic conditions and distribution of selected chemical constituents in water, Snake River Plain aquifer, Idaho National Engineering Laboratory, Idaho, 1986 to 1988: U.S. Geological Survey Water-Resources Investigations Report 91-4047 (DOE/ID-22096), $56 \mathrm{p}$.

Pritt, J.W., 1989, Quality assurance of sample containers and preservatives at the U.S. Geological Survey National Water Quality Laboratory, in Pederson, G.L. and Smith, M.M., compilers, U.S. Geological Survey Second National Symposium on Water Quality-Abstracts of the technical sessions, Orlando, Fla., November 12-17, 1989: U.S. Geological Survey Open-File Report 89-409, $111 \mathrm{p}$.

Pritt, Jeffrey, and Jones, B.E., eds., 1989, 1990 National Water Quality Laboratory Services Catalog: U.S. Geological Survey Open-File Report 89-386, unnumbered.

Rightmire, C.T., and Lewis, B.D., 1987, Hydrogeology and geochemistry of the unsaturated zone, Radioactive Waste Management Complex, Idaho National Engineering Laboratory, Idaho: U.S. Geological Survey Water-Resources Investigations Report 87-4198, 89 p.

Spinazola, J.M., Tungate, A.M., and Rogers, T.L., 1992, Geohydrologic and chemical data from wells in the Mud Lake area, eastern Idaho, 1988-91: U.S. Geological Survey Open-File Report 92-133, 92 p.

Stearns, H.T., and Bryan, L.L., 1925, Preliminary report on the geology and water resources of the Mud Lake Basin, Idaho: U.S. Geological Survey Water-Supply Paper 560-D, p. 87-134.

Toran, Laura, 1982, Isotopes in ground-water investigations: Ground Water, v. 20, no. 6 , p. $740-745$.

U.S. Geological Survey, 1985, National water summary, 1984-Hydrologic events, selected water-quality trends, and ground-water resources: U.S. Geological Survey Water-Supply Paper 2275, $467 \mathrm{p}$.

Wood, W.W., and Low, W.H., 1988, Solute geochemistry of the Snake River Plain regional aquifer system, Idaho and eastern Oregon: U.S. Geological Survey Professional Paper 1408-D, $79 \mathrm{p}$. 
Table 1.-Stable isotopes of hydrogen and oxygen for Big Lost River below Mackay Reservoir near Mackay, Idaho (13127000)

[Location shown in figure 1. Symbols: $\delta^{2} \mathrm{H}$ indicates delta notation for stable hydrogen isotope ratios; $\delta^{18} \mathrm{O}$ indicates delta notation for stable oxygen isotope ratios; permil indicates parts per thousand relative to standard mean ocean water (Craig, 1961); \pm indicates plus or minus; * indicates sample bottle broken enroute to laboratory]

\begin{tabular}{ccc}
\hline Date sampled & $\delta^{2} \mathrm{H}( \pm 1.5$ permil $)$ & $\delta^{18} \mathrm{O}( \pm 0.15$ permil $)$ \\
\hline $03 / 28 / 91$ & -138.0 & -18.00 \\
$05 / 02 / 91$ & -135.0 & -17.85 \\
$05 / 31 / 91$ & -135.0 & -17.75 \\
$07 / 02 / 91$ & -129.0 & -17.20 \\
$07 / 30 / 91$ & -129.0 & -17.05 \\
$08 / 29 / 91$ & -133.0 & -17.30 \\
$10 / 02 / 91$ & -135.0 & -17.80 \\
$11 / 04 / 91$ & -136.0 & -18.00 \\
$12 / 06 / 91$ & $*$ & $*$ \\
$01 / 03 / 92$ & -136.0 & -17.85 \\
$02 / 07 / 92$ & -136.0 & -17.95 \\
$03 / 06 / 92$ & -136 & -18 \\
$04 / 06 / 92$ & -136 & -17.8 \\
$04 / 30 / 92$ & -137 & -17.75 \\
$06 / 18 / 92$ & -134 & -17.45 \\
\hline & &
\end{tabular}


Table 2.-Stable isotopes of hydrogen and oxygen for Little Lost River near Howe, Idaho (13119000)

[Location shown in figure 1. Symbols: $\delta^{2} \mathrm{H}$ indicates delta notation for stable hydrogen isotope ratios; $\delta^{18} \mathrm{O}$ indicates delta notation for stable oxygen isotope ratios; permil indicates parts per thousand relative to standard mean ocean water (Craig, 1961); \pm indicates plus or minus]

\begin{tabular}{ccc}
\hline Date sampled & $\delta^{2} \mathrm{H}( \pm 1.5$ permil $)$ & $\delta^{18} \mathrm{O}( \pm 0.15$ permil $)$ \\
\hline $03 / 28 / 91$ & -137.0 & -18.10 \\
$05 / 02 / 91$ & -136.0 & -18.10 \\
$05 / 31 / 91$ & -137.0 & -18.05 \\
$07 / 02 / 91$ & -137.0 & -18.00 \\
$07 / 30 / 91$ & -138.0 & -18.00 \\
$08 / 29 / 91$ & -137.0 & -17.80 \\
$10 / 02 / 91$ & -139.0 & -18.15 \\
$11 / 04 / 91$ & -139.0 & -18.25 \\
$12 / 16 / 91$ & -139.0 & -18.10 \\
$01 / 03 / 92$ & -139.0 & -18.20 \\
$02 / 07 / 92$ & -139.0 & -18.20 \\
$03 / 06 / 92$ & -139 & -18.25 \\
$04 / 06 / 92$ & -138 & -18 \\
$04 / 30 / 92$ & -137 & -17.85 \\
$06 / 18 / 92$ & -137 & -18.1 \\
\hline
\end{tabular}


Table 3.-Stable isotopes of hydrogen and oxygen for Birch Creek at Blue Dome Inn near Reno, Idaho (13117020)

[Location shown in figure 1. Symbols: $\delta^{2} \mathrm{H}$ indicates delta notation for stable hydrogen isotope ratios; $\delta^{18} \mathrm{O}$ indicates delta notation for stable oxygen isotope ratios; permil indicates parts per thousand relative to standard mean ocean water (Craig, 1961); \pm indicates plus or minus]

\begin{tabular}{ccc}
\hline Date sampled & $\delta^{2} \mathrm{H}( \pm 1.5$ permil $)$ & $\delta^{18} \mathrm{O}( \pm 0.15$ permil $)$ \\
\hline $03 / 28 / 91$ & -143.0 & -18.70 \\
$05 / 02 / 91$ & -140.0 & -18.55 \\
$05 / 31 / 91$ & -141.0 & -18.60 \\
$07 / 02 / 91$ & -140.0 & -18.75 \\
$07 / 30 / 91$ & -142.0 & -18.65 \\
$08 / 29 / 91$ & -141.0 & -18.70 \\
$10 / 02 / 91$ & -142.0 & -18.70 \\
$11 / 04 / 91$ & -142.0 & -18.55 \\
$12 / 06 / 91$ & -142.0 & -18.55 \\
$01 / 03 / 92$ & -142.0 & -18.75 \\
$02 / 07 / 92$ & -142.0 & -18.70 \\
$03 / 06 / 92$ & -142 & -18.75 \\
$04 / 06 / 92$ & -142 & -18.6 \\
$04 / 30 / 92$ & -142 & -18.7 \\
$06 / 18 / 92$ & -142 & -18.65 \\
\hline
\end{tabular}


Table 4.- Stable isotopes of hydrogen and oxygen for Mud Lake near Terreton, Idaho (13115000)

[Location shown in figure 1. Symbols: $\delta^{2} \mathrm{H}$ indicates delta notation for stable hydrogen isotope ratios; $\delta^{18} \mathrm{O}$ indicates delta notation for stable oxygen isotope ratios; permil indicates parts per thousand relative to standard mean ocean water (Craig, 1961); \pm indicates plus or minus]

\begin{tabular}{ccc}
\hline Date sampled & $\delta^{2} \mathrm{H}( \pm 1.5$ permil $)$ & $\delta^{18} \mathrm{O}( \pm 0.15$ permil $)$ \\
\hline $03 / 28 / 91$ & -132.0 & -17.75 \\
$05 / 02 / 91$ & -133.0 & -17.60 \\
$05 / 31 / 91$ & -134.0 & -17.85 \\
$07 / 02 / 91$ & -131.0 & -17.75 \\
$07 / 30 / 91$ & -133.0 & -17.70 \\
$08 / 29 / 91$ & -134.0 & -17.85 \\
$10 / 02 / 91$ & -135.0 & -17.75 \\
$11 / 04 / 91$ & -133.0 & -17.30 \\
$12 / 06 / 91$ & -129.0 & -16.70 \\
$01 / 03 / 92$ & -130.0 & -16.90 \\
$02 / 07 / 92$ & -135.0 & -17.50 \\
$03 / 06 / 92$ & -122 & -15.55 \\
$04 / 06 / 92$ & -133 & -17.6 \\
$04 / 30 / 92$ & -135 & -17.7 \\
$06 / 18 / 92$ & -134 & -17.8 \\
\hline & & \\
\hline & &
\end{tabular}


Table 5.-Stable isotopes of hydrogen and oxygen for selected wells and a spring on or near the Idaho National Engineering Laboratory, Idaho

[Locations shown in figure 2. Use category: $C$ indicates commercial operation; $D$ indicates domestic well; I indicates irrigation well; $M$ indicates water-quality monitoring well; $P$ indicates production well; and QA indicates quality assurance for preceding sample. Symbols: $\delta^{2} \mathrm{H}$ indicates delta notation for stable hydrogen isotope ratios; $\delta^{18} \mathrm{O}$ indicates delta notation for stable oxygen isotope ratios; permil indicates parts per thousand relative to standard mean ocean water (Craig, 1961); \pm indicates plus or minus]

\begin{tabular}{|c|c|c|c|c|}
\hline Sample identifier & Use category & Date sámpled & $\delta^{2} \mathrm{H}( \pm 1.5$ permil $)$ & $\delta^{18} \mathrm{O}( \pm 0.15$ permil $)$ \\
\hline USGS 1 & $\mathbf{M}$ & $05 / 30 / 91$ & -135.0 & -18.00 \\
\hline USGS 2 & $\mathbf{M}$ & $05 / 28 / 91$ & -135.0 & -17.95 \\
\hline QAC-2 & QA & 05/28/91 & -134.0 & -17.95 \\
\hline USGS 4 & $\mathbf{M}$ & $06 / 04 / 91$ & -120.0 & -14.95 \\
\hline QAC-3 & QA & 06/04/91 & -120.0 & -14.95 \\
\hline USGS 7 & M & 05/20/91 & -136.0 & -18.10 \\
\hline QAC-1 & QA & 05/20/91 & -137.0 & -18.00 \\
\hline USGS 8 & M & $05 / 31 / 91$ & -137.0 & -18.00 \\
\hline USGS 9 & $\mathrm{M}$ & $05 / 31 / 91$ & -136.0 & -18.00 \\
\hline USGS 17 & M & $06 / 06 / 91$ & -137.0 & -17.65 \\
\hline USGS 19 & $\mathrm{M}$ & $05 / 21 / 91$ & -136.0 & -18.10 \\
\hline USGS 20 & M & $05 / 30 / 91$ & -139.0 & -18.10 \\
\hline USGS 23 & M & $05 / 21 / 91$ & -137.0 & -18.25 \\
\hline USGS 26 & M & $05 / 23 / 91$ & -136.0 & -18.00 \\
\hline USGS 27 & $\mathbf{M}$ & $05 / 23 / 91$ & -135.0 & -17.85 \\
\hline USGS 29 & M & $06 / 12 / 91$ & -134.0 & -17.65 \\
\hline USGS 31 & M & $06 / 12 / 91$ & -136.0 & -17.90 \\
\hline USGS 32 & M & $06 / 12 / 91$ & -135.0 & -17.75 \\
\hline USGS 57 & M & $05 / 13 / 91$ & -136.0 & -17.70 \\
\hline USGS 65 & M & $05 / 16 / 91$ & -133.0 & -16.90 \\
\hline USGS 85 & $\mathbf{M}$ & $06 / 04 / 91$ & -136.0 & -17.90 \\
\hline USGS 86 & $\mathbf{M}$ & $05 / 31 / 91$ & -139.0 & -18.30 \\
\hline
\end{tabular}


Table 5.-Stable isotopes of hydrogen and oxygen for selected wells and a spring on or near the Idaho National Engineering Laboratory, Idaho-Continued

\begin{tabular}{lcccc}
\hline \multicolumn{1}{c}{ Sample identifier } & Use category & Date sampled & $\delta^{2} \mathrm{H}( \pm 1.5$ permil $)$ & $\delta^{18} \mathrm{O}( \pm 0.15$ permil $)$ \\
\hline USGS 101 & $\mathrm{M}$ & $05 / 15 / 91$ & -135.5 & -18.00 \\
USGS 110 & $\mathrm{M}$ & $05 / 08 / 91$ & -133.0 & -17.80 \\
USGS 112 & $\mathrm{M}$ & $05 / 13 / 91$ & -136.5 & -17.65 \\
CFA-1 & $\mathrm{P}$ & $06 / 19 / 91$ & -137.0 & -17.55 \\
CPP-1 & $\mathrm{P}$ & $06 / 06 / 91$ & -137.0 & -17.85 \\
EBR-1 & $\mathrm{P}$ & $06 / 19 / 91$ & -139.0 & -18.35 \\
Fire Station 2 & $\mathrm{P}$ & $06 / 19 / 91$ & -139.0 & -18.15 \\
Lidy Hot Springs & $\mathrm{C}$ & $08 / 20 / 92$ & -135. & -18.1 \\
McKinney Well & $\mathrm{D}$ & $06 / 13 / 91$ & -141.0 & -18.55 \\
No Name No. 1 & $\mathrm{M}$ & $05 / 22 / 91$ & -128.0 & -16.10 \\
NPR Test & $\mathrm{M}$ & $06 / 20 / 91$ & -137.0 & -17.75 \\
P\&W 2 & $\mathrm{M}$ & $05 / 22 / 91$ & -140.0 & -18.55 \\
Park Bell Well & $\mathrm{I}$ & $06 / 11 / 91$ & -135.0 & -17.90 \\
Ruby Farms Well & $\mathrm{D}$ & $05 / 10 / 91$ & -138.0 & -18.15 \\
Site 9 & $\mathrm{M}$ & $06 / 25 / 91$ & -137.0 & -17.95 \\
Site 14 & $\mathrm{M}$ & $06 / 13 / 91$ & -136.0 & -18.00 \\
Site 17 & $\mathrm{M}$ & $06 / 18 / 91$ & -140.0 & -18.15 \\
QAC-4 & $\mathrm{QA}$ & $06 / 18 / 91$ & -139.0 & -18.15 \\
Site 19 & $\mathrm{M}$ & $05 / 09 / 91$ & -138.0 & -18.10 \\
Stoddart Well & $\mathrm{D}$ & $06 / 12 / 91$ & -135.0 & -17.85 \\
\hline
\end{tabular}

